\title{
The connective tissue index of Helix aspersa as a metal biomarker
}

\author{
André Filipe Santos Amaral*, Henrique Anselmo, Regina Maria Pires Toste Tristão da Cunha \\ \& Armindo Santos Rodrigues \\ Universidade dos Açores, Departamento de Biologia, R. Mãe de Deus, 9500 Ponta Delgada, São Miguel, Açores, \\ Portugal*Author for correspondence (E-mail: aamaral@notes.uac.pt)
}

Received 12 September 2003; Accepted 8 March 2004; Published online October 2004

Key words: Helix aspersa, digestive gland, connective tissue, copper, iron

\begin{abstract}
The digestive gland of adult land snails, Helix aspersa, sampled from four different sites in São Miguel island (Azores) was submitted to chemical analyses, autometallography and haemalum/eosin staining, in order to quantify the relative abundance of heavy metals, calcium cells and connective tissue cells. Metals were visualized, through light microscopy, as black silver deposits mostly in the connective tissue cells. Metal levels, essentially of $\mathrm{Cu}$ and $\mathrm{Fe}$, were related to the relative volumetric density of connective tissue cells but not to the relative volumetric density of calcium cells from the digestive gland epithelium. Thus, the connective tissue index presented herein is suggested as a biomarker of $\mathrm{Cu}$ exposure in terrestrial mollusks.
\end{abstract}

\section{Introduction}

The digestive gland is the most important organ participating in xenobiotic detoxification in mollusks. This organ is responsible for the production of digestive enzymes, nutrient absorption and digestion, endocytosis of food substances, food storage and excretion (Owen 1996). The digestive gland epithelium of terrestrial gastropods is composed of three cell types (Dimitriadis 2001): digestive cells, calcium cells, and excretory cells. The most frequent cell type to be found in this epithelium of Stylommatophora is the digestive cell, which is directly involved in the digestive process. Excretory cells are less numerous and concerned with the excretion of wastes. The calcium cells are characterized by the presence of calcium granules, occurring in large numbers in Helix aspersa (approximately $10^{3}$ per cell), for the most part in the form of phosphate (Fournié \& Chétail 1982, Simkiss \& Taylor 1994). Besides epithelial cells, digestive gland also comprises connective tissue, which is composed by rhogocytes (pore cells), pigment cells, and fibroblasts, among others. Rhogocytes are implicated in hemocyanin formation, collagen synthesis, and accumulation of calcium leading to development into calcium cells, and metal detoxification (Luchtel \& Deyrup-Olsen 2001).

Among the multiple functions attributed to the digestive gland of mollusks, it is also known to be a major target site for metal accumulation, involved in metal sequestering and release (Ireland \& Marigómez 1992, Soto 1995). Such actions show histological and histochemical changes that can be used as biomarkers of metal exposure.

The aim of this study was to determine if animals from qualitatively different areas are significantly different from each other in metal metabolism, and if differences in that metabolism can be detected in the digestive gland epithelium and connective tissue.

\section{Material and methods}

The Azores archipelago is located in the North Atlantic Ocean at the triple junction of Eurasian, African and North American plates, characterized by a complex tectonic settlement, where the seismic and volcanic phenomena are common (Nunes et al., 1993). The Azores archipelago is remote from heavy industrial activities despite of the expanding tourism, 
meaning that its volcanic activity must be considered when studying the availability of trace metals. The four sampling sites of the present work are located in the island of São Miguel: (1) Fuel deposits, with scarce vegetation, is next to a commercial seaport, and stands next to a road with a car traffic frequency of about 500 cars per hour; (2) Rotunda of Belém, though having more vegetation than Fuel deposits, is the main point of entry and exit from Ponta Delgada, which is the main city, and for this it has one of the highest car traffic frequency (about 2000 cars per hour); (3) Backyard, inside the historic zone of Ponta Delgada (less than 100 cars per hour); and (4) Lombadas (control station), with dense vegetation, partially composed by endemic species, stands $20 \mathrm{~m}$ from a rarely used road and $4 \mathrm{~km}$ from the nearest village.

Sixty adult snails of $H$. aspersa, fifteen per site, were collected. In the laboratory, the digestive glands of snails were excised under a Wild M3 stereomicroscope.

For chemical analysis, digestive glands were dried $\left(130^{\circ} \mathrm{C}\right)$, digested in nitric acid, and finally dissolved in $0.1 \mathrm{~N}$ HNO3. Metal concentrations ( $\mathrm{Al}, \mathrm{Cd}, \mathrm{Cu}, \mathrm{Fe}$, $\mathrm{Pb})$ were measured by an atomic absorption spectrophotometer (GBC 906AA).

One tissue sample from each digestive gland was fixed in neutral buffered formaldehyde (Hopwood 1996), dehydrated in alcohol, cleared in methylbenzoate (overnight), rinsed in benzene, embedded in paraffin and sectioned at $7 \mu \mathrm{m}$ thickness.

A set of sections was submitted to an autometallographic procedure (Soto et al. 1998) in order to demonstrate metals while another was stained with haemalum and eosin (Martoja \& Martoja-Pierson 1970) to estimate the relative volumetric density of calcium cells and connective tissue cells. Paraffin sections were dewaxed in xylene, hydrated in ethanolwater mixtures and left in an oven at $37^{\circ} \mathrm{C}$ until completely dried. Tissues sections were covered with a photographic emulsion (Ilford Nuclear Emulsion L4) under safety light conditions. After drying for $30 \mathrm{~min}$ in total darkness, sections were rinsed in a developer bath (1:5, b/w Ilford PQ Universal) for $15 \mathrm{~min}$, rinsed in a stop bath ( $1 \%$ acetic acid) for $1 \mathrm{~min}$, and finally rinsed in a fixative bath (1:10, b/w Ilford Hypam) for $10 \mathrm{~min}$.

The relative volumetric density of black silver deposits ( $\mathrm{Vv}_{\mathrm{BSD}}$ ) was estimated using the M168 Weibel Multipurpose Test System (Weibel 1979). The same methodology was applied to the haemalum and eosin sections to estimate the relative volumetric density
Table 1. Metal concentrations in the digestive gland of H. aspersa ( $\mu \mathrm{g}$ metal/g dry tissue).

\begin{tabular}{lrrl}
\hline Sampling stations & \multicolumn{1}{l}{$\mathrm{Al}$} & $\mathrm{Cu}$ & $\mathrm{Fe}$ \\
\hline Fuel Deposits & 223,15 & 209,48 & 670,01 \\
Rotunda of Belém & 171,74 & 130,72 & 486,78 \\
Backyard & 40,47 & 73,26 & 237,21 \\
Lombadas & 583,33 & 49,02 & 171,88 \\
\hline
\end{tabular}

of calcium cells $\left(\mathrm{V}_{\mathrm{CC}}\right)$ and the relative volumetric density of connective tissue cells $\left(\mathrm{V}_{\mathrm{CTC}}\right)$. Before proceeding with statistical analysis, $\mathrm{Vv}_{\mathrm{BSD}}, \mathrm{Vv}_{C C}$ and $\mathrm{Vv}_{\mathrm{CTC}}$ values were normalized using the arcsine transformation (Sokal \& Rohlf 1995).

A one-way analysis of variance was performed (Sokal \& Rohlf 1995) in order to determine the effect of locality (L) on the $\mathrm{Vv}_{\mathrm{BSD}}, \mathrm{Vv}_{\mathrm{CC}}$ and $\mathrm{Vv}_{\mathrm{CTC}}$ levels in the digestive gland of $H$. aspersa. This was complemented with a Duncan test $(p \leq 0.05)$, using the SPSS software (SPSS Inc., Microsoft Co.). Correlations between $\mathrm{V}_{\mathrm{v}_{\mathrm{BSD}}}, \mathrm{V}_{\mathrm{v}_{\mathrm{CC}}}, \mathrm{V}_{\mathrm{v}_{\mathrm{CTC}}}$ and metals were also determined.

\section{Results}

Metal accumulation has been detected in the digestive gland of $H$. aspersa from all four sampling sites (Table 1). Values of $\mathrm{Cd}$ and $\mathrm{Pb}$ were very low in all snails.

The calcium cell composition of the digestive gland epithelium sections, from the four sampling sites, did not differ (Duncan test, $p>0.05$ ). However, when observing the stroma of the gland, Rotunda of Belém and Fuel deposits evidenced more and larger connective tissue cells than Lombadas and Backyard (Figures $1 \mathrm{~A}-\mathrm{B}$ and 2). The $\mathrm{Vv}_{\mathrm{CTC}}$ of Rotunda of Belém presented the highest value, being significantly different from the Backyard and Lombadas (Duncan test, $p \leq 0.05$ ) but not from the Fuel deposits (Duncan test, $p>0.05$ ) (Figure 2).

Metals occurred essentially inside the connective tissue cells, mainly rhogocytes, and few in the digestive cells and the basal lamina beneath it, while calcium cells were devoid of BSD (Figure 1C-D). Metal accumulation was significantly higher in Rotunda of Belém and Fuel deposits when compared with Lombadas and Backyard (Duncan test, $p \leq 0.05$ ). There were no 


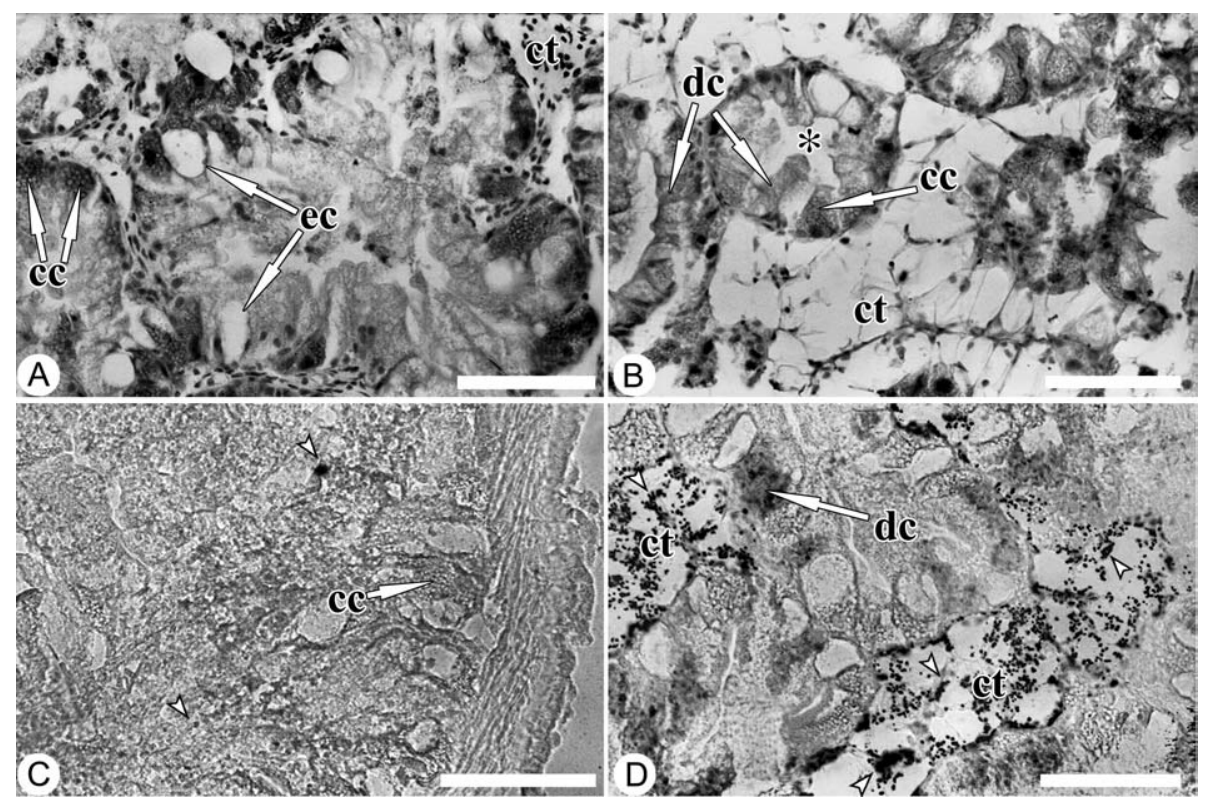

Fig 1. (A) Section of the digestive gland of a specimen from Lombadas, stained with haemalum and eosin, showing normal connective tissue cells (ctc), calcium cells (cc) and excretory cells (ec). (B) Section of the digestive gland of a specimen from Rotunda of Belém, stained with haemalum and eosin. Note the acini with normal digestive cells (dc), calcium cells (cc) and excretory cells surrounded by large connective tissue cells (ctc). (C) Autometallographic demonstration of metal deposits (arrow head) in the digestive gland of a specimen from Lombadas. Note the scarcity of metal deposits. D- Autometallographic demonstration of metal deposits in the digestive gland of a specimen from Rotunda of Belém. Note the abundance of metal deposits (arrow head) present in the connective tissue cells (ctc) and their absence in calcium cells (cc). Scale bar $=10 \mu \mathrm{m}$.

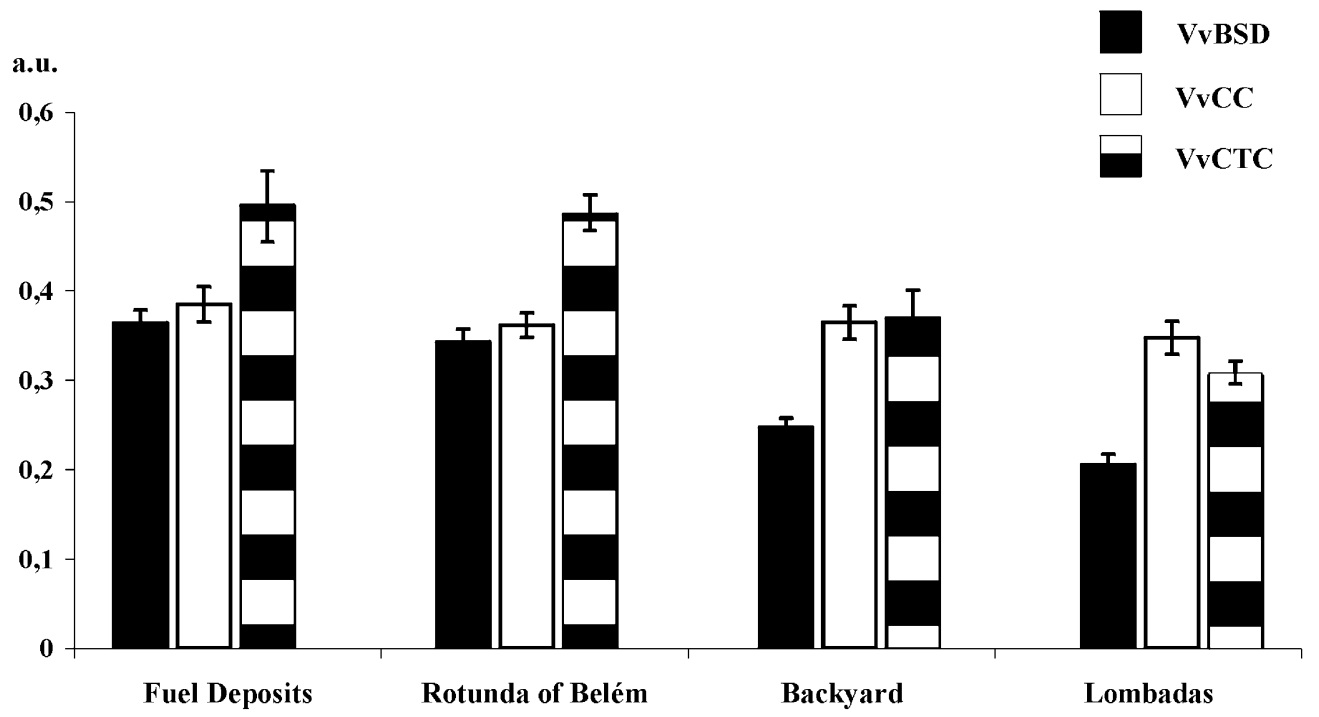

Fig 2. (Semi)quantification, by means of volume density, of metals $\left(\mathrm{Vv}_{\mathrm{BSD}}\right)$, calcium cells $\left(\mathrm{Vv}_{\mathrm{CC}}\right)$ and connective tissue cells $\left(\mathrm{Vv}_{\mathrm{CTC}}\right)[\overline{\mathrm{x}} \pm$ se] in the digestive gland of $H$. aspersa. a. u.= arbitrary units. 
Table 2. Pearson's correlation between variables. ${ }^{*}, p \leq 0.5$; $^{* *}, p \leq 0.01$.

\begin{tabular}{|c|c|c|c|c|c|c|}
\hline Variable & $\mathrm{V}_{\mathrm{v}_{\mathrm{BSD}}}$ & $\mathrm{Vv}_{\mathrm{CTC}}$ & $\mathrm{Vv}_{\mathrm{CC}}$ & $\mathrm{Al}$ & $\mathrm{Cu}$ & $\mathrm{Fe}$ \\
\hline $\mathbf{V} \mathbf{v}_{\text {BSD }}$ & & $0,565^{* *}$ & $0,146 \ldots$ & $-0,382^{* *}$ & $0,751^{* *}$ & $0,779^{* *}$ \\
\hline $\mathbf{V v}_{\text {CTC }}$ & & & $0,311 * .$. & $-0,322 * .$. & $0,540 * *$ & $0,566^{* *}$ \\
\hline $\mathbf{V} \mathbf{v}_{\mathrm{CC}}$ & & & & $-0,110 \ldots$ & $0,179 \ldots$ & $0,169 \ldots$ \\
\hline
\end{tabular}

significant differences between Rotunda of Belém and Fuel deposits (Duncan test, $p>0.05$ ) (Figure 2).

According to the one-way analysis of variance, locality (L) affected significantly $\mathrm{Vv}_{\mathrm{BSD}}(\mathrm{F}=33.398$; $p \leq 0.01)$ and $\mathrm{V}_{\mathrm{CTC}}(\mathrm{F}=10.389 ; p \leq 0.01)$ but not $\mathrm{Vv}_{\mathrm{CC}}(\mathrm{F}=0.754 ; p>0.05)$. A significant Pearson correlation $(p \leq 0.01)$ was detected between $\mathrm{Vv}_{\mathrm{BSD}}$ and $\mathrm{Vv}_{\mathrm{CTC}}$ (Table 2).

\section{Discussion}

Autometallography has been earlier reported to be a useful and sensitive technique for the localization and quantification of metal deposits in cellular compartments of marine and terrestrial mollusks (Marigómez et al. 1996, Soto et al. 1996, Marigómez et al. 1998, Soto et al. 1998). In the present work, metals were visualized under the light microscope as BSD in the connective tissue but not in the calcium cells of the digestive gland epithelium. These observations are in agreement with previous results of Zaldibar et al. (1998) for freshwater snails. The BSD extent $\left(\mathrm{V}_{\mathrm{BSD}}\right)$ in the digestive gland presented significant differences between sites with different metal bioavailability, being $\mathrm{Cu}$ and $\mathrm{Fe}$ the most correlated to $\mathrm{Vv}_{\mathrm{BSD}}$ levels.

Changes in relative cell-type proportion (RCP) of the digestive gland have been proposed as a metal biomarker that reflects high levels of bioavailable metals in the environment (Marigómez et al. 1998). Previous laboratory experiments recorded high BSD extent accompanied by changes in RCP of the digestive gland epithelium (Marigómez et al. 1996, 1998). In the present study, quantification of calcium cells $\left(\mathrm{V}_{\mathrm{CC}}\right)$ revealed that snails from all studied sites exhibited very similar epithelial composition, but in contrast, snails from the two sites with highest metal bioavailability demonstrated more and larger connective tissue cells. This increase in the proliferation of connective tissue cells was also related to $\mathrm{Cu}$ and $\mathrm{Fe}$, and has been earlier reported in winkles after their exposure to $\mathrm{Cu}$ and $\mathrm{Zn}$ (Soto et al. 1999). A possible explanation to this event is the existence of $\mathrm{Fe}$ and $\mathrm{Cu}$ granules inside rhogocytes (Haszprunar 1996) and the role of these cells in the formation of hemocyanin and metal detoxification (Luchtel \& Deyrup-Olsen 2001), meaning that rhogocytes may react promptly and earlier than epithelial calcium cells when facing high levels of $\mathrm{Fe}$ and $\mathrm{Cu}$ exposure in the environment. One fact supporting this is the exclusive occurrence of Cu-MT mRNA in rhogocytes (Chabikovsky 2003). Thus, changes in connective tissue rhogocytes may be used as an early warning in $\mathrm{Fe}$ and, especially, $\mathrm{Cu}$ contamination.

\section{Acknowledgements}

The authors thank Professor Patricia Garcia for helpful discussions and comments, and Dr. Jorge Medeiros for imaging assistance. The present work has been financially supported by Centro de Investigação em Recursos Naturais (CIRN), University of the Azores.

\section{References}

Chabicovsky M, Niederstätter H, Thaler R, Hödl E, Parson W, Rossmanith V, Dallinger R. 2003. Localization and quantification of $\mathrm{Cd}$ - and $\mathrm{Cu}$-specific metallothionein isoform mRNA in cells and organs of the terrestrial gastropod Helix pomatia. Toxicol Appl Pharm 190, 25-36.

Dimitriadis VK. 2001 Structure and function of the digestive system in Stylommatophora. In: Barker GM, ed. The Biology of Terrestrial Molluscs. Wallingford: CABI Publishing: 237-257.

Fournié J, Chétail M. 1982 Accumulation calcique au niveau cellulaire chez les mollusques. Proceedings Seventh International Malacological Congress, Coloque Calcium et Structures Squelettiques. Malacologia 22, 265-284.

Haszprunar G. 1996 The molluscan rhogocyte (pore-cell, blasenzelle, cellule nucale), and its significance for ideas on nephridial evolution. J Moll Stud 62, 185-211.

Hopwood D. 1996 Fixation and fixatives. In: Bancroft JD, Stevens A, eds. Theory and Practice of Histological Techniques, 4th ed. Hong Kong: Churchill Livingstone: 23-46.

Ireland MP, Marigómez I. 1992 The influence of dietary calcium on the tissue distribution of $\mathrm{Cu}, \mathrm{Zn}, \mathrm{Mg} \& \mathrm{P}$ and histological changes in the digestive gland cells of the snail Achatina fulica Bowdich. J Moll Stud 58, 157-168. 
Luchtel DL, Deyrup-Olsen I. 2001 Body wall: form and function. In: Barker GM, ed. The Biology of Terrestrial Molluscs. Wallingford: CABI Publishing: 147-178.

Marigómez I, Soto M, Kortabitarte M. 1996 Tissue-level biomarkers and biological effect of mercury on sentinel slugs, Arion ater. Arch Environ Contam Toxicol 31, 54-62.

Marigómez I, Kortabitarte M, Dussart GBJ. 1998 Tissue-level biomarkers in sentinel slugs as cost-effective tools to assess metal pollution in soils. Arch Environ Contam Toxicol 34, 167-176.

Martoja R, Martoja-Pierson M. 1970 Técnicas de Histología Animal. Barcelona: Toray Masson S.A.

Nunes JC, Carvalho MR, Forjaz VH. 1993 Short note on São Miguel Island (Azores) tiltmeters. Açoreana 7(4), 633-641.

Owen G. 1966 Digestion. In: Wilbur KM, Yonge CM, eds. Physiology of Mollusca, Vol 2, New York: Academic Press: 53-96.

Simkiss K, Taylor MG. 1994 Calcium magnesium phosphate granules: atomistic simulations explaining cell death. J Exp Biol 190, 131-139.
Sokal RR, Rohlf FJ. 1995 Biometry. 3rd ed. New York: WH Freeman and Company.

Soto M, Cajaraville MP, Angulo E, Marigómez I. 1996 Autometallographic localization of protein-bound copper and zinc in the common winkle, Littorina littorea: a light microscopical study. Histochem J 28, 689-701.

Soto M, Quincoces I, Marigómez I. 1998 Autometallographical procedure for the localization of metal traces in molluscan tissues by light microscopy. J Histotechnol 21(2), 123-127.

Soto M, Lekube X, Marigómez I. 1999 Autometallographical localisation of $\mathrm{Cu}$ and $\mathrm{Zn}$ within target cell compartments of winkles following exposure to $\mathrm{Cu} \& \mathrm{Zn}$ mixtures. Eur J Histochem 43, 323-334.

Weibel ER. 1979 Stereological methods.London: Academic Press Inc.

Zaldibar B, Rodrigues A, Lopes M, Marigómez I, Soto M. 1998 Tissue-level biomarkers in freshwater molluscs to assess natural metal pollutants due to volcanicity. Cuadernos de Investigación Biológica 20, 313-316. 